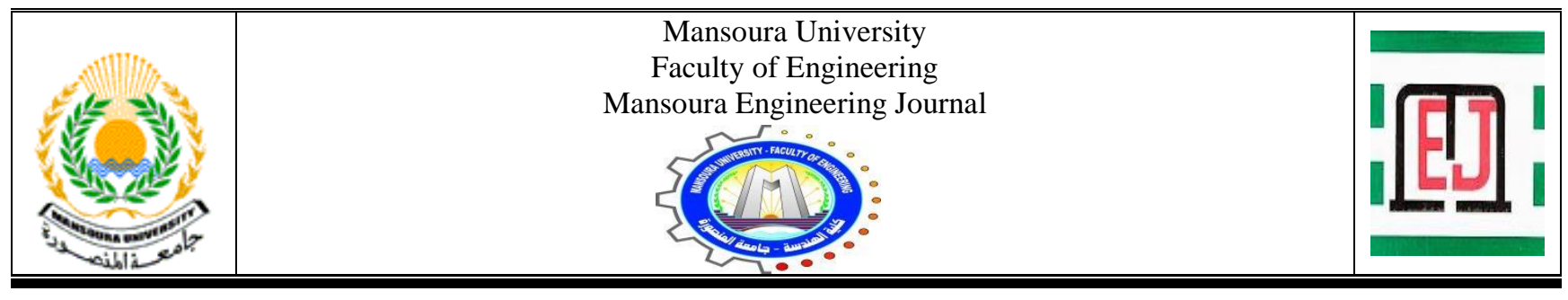

\title{
Iron (II) Absorption from Groundwater by Natural Peat Soil at its in-Situ Conditions
}

\author{
Moharram Fouad, Mohamed I. Gad, Mahmoud H. Mustafa and Enas E. Ali*
}

\begin{tabular}{|lr|}
\hline \multicolumn{2}{|c|}{ KEYWORDS: } \\
Adsorption & technique, \\
peat soil, & adsorption \\
removal & efficiency, \\
Adsorption & capacity, \\
pollutants & \\
& \\
\end{tabular}

\begin{abstract}
Contamination of groundwater with heavy metals may have harmful effects on the lives of people who depend on groundwater for drinking and other life purposes. Several techniques were used to remove the pollutants from the water, such as chemical precipitation, ion exchange, coagulation, electrochemical treatment, and adsorption. The last method is preferred due to its simplicity, easy recovery, and high effectiveness. Chemical analysis of the natural peat soil and the Fe (II) aqueous solution were performed. The characteristics of the soil were identified using X-ray diffraction (XRD), scanning electron microscope (SEM), and X-ray fluorescence (XRF).

Furthermore, experimental work was carried out to investigate the effect of operational parameters on the removal -efficiency \% and adsorption capacity of natural peat to remove pollutants from aqueous solution. The operating parameters were the contact time, $\mathrm{Fe}$ initial concentration, adsorbent thickness, and adsorbent dose. The results explained that the natural peat soil was very effective for pollutant removal from an aqueous solution.
\end{abstract}

\section{INTRODUCTION}

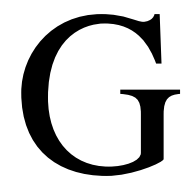

ENERALLY, groundwater pollution with high concentrations of iron (Fe (II)) may cause serious harm to humans, plants, and animals because of its [1-3]. High concentration of $\mathrm{Fe}$ (II) inside groundwater comes from several sources, such as industrial activities [4-5], agriculture activities [6], mining [7-8], fertilizers [9], and oxidation ponds seepage [10-11].

$\mathrm{Fe}$ (II) high concentration may cause breathing rate, coughing, and severe health problems such as abdominal pain,

Received: (02 December, 2020) - Revised: (26 March, 2021) - Accepted: (04 April, 2021)

Corresponding Author: Enas E. Ali, is researcher at Puplic Work, Faculty of engineering, Mansoura University, Mansoura\& is with National Center of Water Research, Cairo, Egypt (e-mail: ali.enas75@yahoo.com).

M. Fouad is Associate Professor with the Engineering Department of Public Works, Faculty of Engineering, Mansoura University, Mansoura, Egypt (e-mail: m123f12317@yahoo.com).

M. I. Gad, professor of Hydrology and water resources, Desert Research Center, Cairo, Egypt, (e-mail: drmohamedgad@yahoo.com)

Mahmoud H. Mustafa, Associate professor, Geology Department, Faculty of Petroleum and Mining, Suez University. (e-mail:m.h.moustafa@gmail.com) vomiting, and nausea [12]. So, the maximum acceptable concentration of $\mathrm{Fe}$ (II) ions for drinking water must not exceed $0.3 \mathrm{mg} / \mathrm{l}$ [13]. Consequently, the removal of Fe (II) ions from groundwater inside or outside the soil are necessary and an urgent need. Several actions have a significant effect on the reduction of Fe (II) ions inside the soil, such as ion exchange [14], reduction precipitation [15-20], coagulation and flocculation [21], and adsorption [22-24].

Several researchers have confirmed that natural adsorption can occur inside soil, reducing the concentration of some metals [25-27]. Various materials that exist inside soil have adsorbent action such as clay [28], kaolinite [29-30], vermiculite [31-32], bentonite [33], soil [34], perlite [35], calcite [36], zeolite [37], activated carbon [38-39], and peat [8, 40].

In [24], a highly efficient and low-cost sludge from a drinking water treatment plant is used as an adsorbent material to remove copper ions. The results indicated that the initial concentration of the copper ions is directly proportional to the sorption capacity of the sludge. On the other hand, the adsorbent dosage has an inverse relation with the sorption capacity of the sludge. Furthermore, the removal efficiency and the sorption capacity are high when $\mathrm{pH}$ is 6.6 , and the temperature is $60^{\circ} \mathrm{C}$. In [41], oil shell rock is used to remove 
metal ions ( $\mathrm{Pb}$ (II) from an aqueous solution. The clay of kaolinite adsorbs $\mathrm{Pb}$ (II) greater than the other metals. The $\mathrm{pH}$ greatly affects the kaolinite's adsorption capacity. The experimental results explained that the removal efficiency was influenced by $\mathrm{pH}$, initial concentration of ions, contact time, and adsorbent concentration. The removal \% of $\mathrm{Pb}$ (II) using Kaolinite/Smectite reached $75 \%$ at 120 min. In [42], indicated that $\mathrm{US} / \mathrm{PS} / \mathrm{Fe}_{3} \mathrm{O}_{4}$ process can effectively and efficiently aid the surface adsorption of CIP-F from aqueous solutions with $98.3 \%$ of removal efficiency percentage at $\mathrm{pH}=5$, CIP-F concentration $=200 \mathrm{mg} / \mathrm{L}$, PS concentration $=0.15 \mathrm{~mol} / \mathrm{L}$ and $\mathrm{Fe}_{3} \mathrm{O}_{4}$ concentration $=0.01 \mathrm{~g} / \mathrm{L}$ at a resident time of $45 \mathrm{~min}$.

In the present study, a natural peat soil acts as a protecting layer of groundwater aquifer in the north Delta. It was collected from digging pipelines in Dakahlia Governorate's villages, as shown in Figure 1. It has high adsorption properties and is called coaled organic soil. It was used as natural adsorbent material, which was considered commercial, inexpensive, and available. It had organic matter content of $2.49 \%$ and $\mathrm{pH}$ values of 6.51. The natural peat was characterized using XRD, XRF, and SEM to determine its constituents, size, and phase of its compounds. Experimental works were conducted to study the change of the water properties when passing through this adsorbent material. The effect of some parameters such as the contact time, initial concentration, adsorbent thickness, and adsorbent dose on the removal efficiency (\%) and adsorption capacity was also investigated.
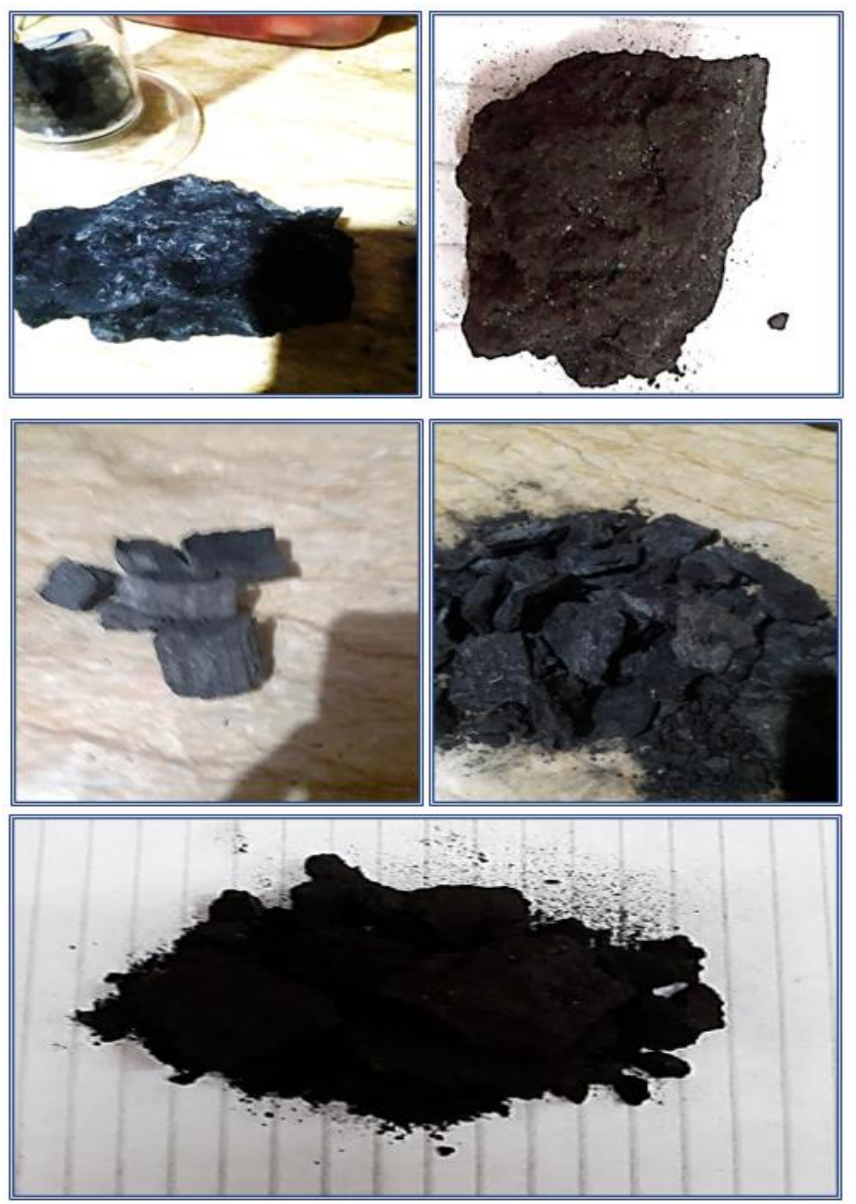

Fig. 1. Different types of the collected adsorbent material.

\section{MATERIALS AND METHODOLOGY}

In this study, column experiments were performed to study Fe (II) 's adsorption behavior in groundwater through natural peat soil. The adsorbent material was broken into small sizes and put into graduated cylinders $(1000 \mathrm{ml}$ in size and $5 \mathrm{~cm}$ in inner diameter), as shown in Figure 2. The standard synthetic Fe (II) solutions $1000(\mathrm{mg} / \mathrm{L})$ was prepared by dissolving an appropriate amount of $\mathrm{Fe}(\mathrm{OH})_{2}$. The solution was diluted to the required concentrations before being utilized. 12.5, 25, 50, and $100 \mathrm{mg} / \mathrm{L}$ as $\mathrm{Fe}$ initial concentration in water were used. A Ferose F medical tablet is the source of Fe (100 mg Ferric Hydroxide Polymaltose complex).

Experiments were conducted in glass columns packed with $50,95,175$, and $210 \mathrm{~g}$ of dry adsorbent material to investigate the influence of different doses on Fe's adsorption from an aqueous solution. $\mathrm{Fe}$ aqueous solution was observed periodically, and chemical analysis after 5, 10, 15, and $20 \mathrm{hrs}$ was done, as shown in Figure 2. There is mixing made in these durations to react with the ferrous solution, but Figure 2A, B, $\mathrm{C}, \mathrm{D}$ began before mixing.

A series of laboratory experiments were conducted to investigate operational conditions $\mathrm{Fe}$ initial concentration, contact time, and adsorbent dose on the removal efficiency and adsorption capacity. The $\mathrm{Fe}$ initial concentration was increased from 12.5 to $100 \mathrm{mg} / \mathrm{L}$, the adsorbent dose was changed from 50 to $210 \mathrm{~g}$ (50, 95, 175, and $210 \mathrm{~g}$ ), and the contact time varied from 5 to $20 \mathrm{hrs}$. The aqueous solution temperature was a room temperature $\left(25^{\circ} \mathrm{C}\right)$. The $\mathrm{pH}$ value of the aqueous solution was measured as 7.4. The change of $\mathrm{pH}$ and temperature were being neglected, and all experiments were carried out at room temperature $\left(25^{\circ} \mathrm{C}\right)$.

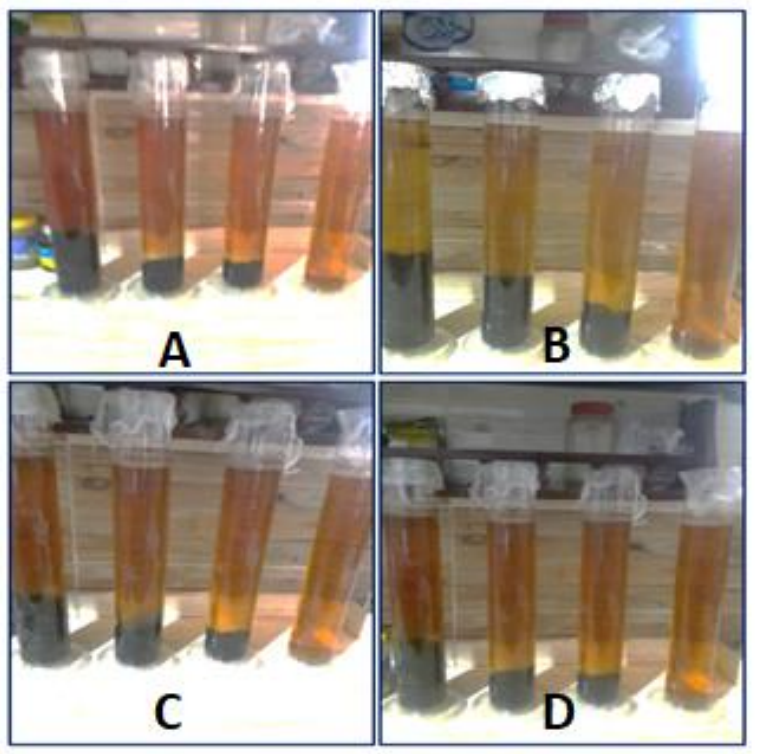

Fig. 2. The Fe (II) aqueous solution with different weights of the adsorbent material.

The aqueous solution and soil peat samples were analyzed for various physical methods and chemical parameters according to the standard for examining water (EPA, 2008). Water $\mathrm{pH}$ was determined using bench-top $\mathrm{pH} / \mathrm{ISE}$ meter, 
ORION model 710A. Electric conductivity (EC) of water samples was measured at $25^{\circ} \mathrm{C}$ as standard temperature using ATC Bench Electric Conductivity Meters, HANNA, model HI 8820. The total dissolved solids (TDS) in the water samples were determined gravimetrically. Major anions were determined using ion chromatography (IC) Model DX-ICS 5000, USA. Essential cations and heavy metals were determined using the Inductively Coupled Plasma-Emission spectrometry (ICP-OES) with Ultra Sonic Nebulizer (USN) (model Perkin Elmer optima 5300, USA).

Soil $\mathrm{pH}$ was determined by a glass electrode in distilled water suspensions at the soil to water ratio, 1:2.5. Electrical conductivity (EC) was measured using a conduct-meter in filtrates from soil/water suspensions, 1:2. The concentrations of heavy metals were determined in microwave-assisted digests (Multiwave Perkin Elmer 3000) of soil samples added with suprapure $\mathrm{HNO}_{3} / \mathrm{H}_{2} \mathrm{O} / \mathrm{HCl}, 5: 1: 1 \mathrm{v} / \mathrm{v}$. The concentrations $(\mathrm{mg} / \mathrm{kg})$ of heavy metals in acid-digested extracts were determined using inductively coupled plasma-optical emission spectrometry (ICP-OES).

\section{Characterization Of The Adsorbent Material}

The adsorbent material was characterized using XRD, $\mathrm{XRF}$, and SEM to determine its constituents, size, and phase of its compounds.

\section{$X$-ray Diffraction $(X R D)$}

The phase compositions and structures of the tested sample were characterized by X-ray diffraction (XRD). A Broker axis D8 diffract meter using $\mathrm{Cu}-\mathrm{K} \alpha\left(\lambda \_1.5406\right)$ radiation and secondary monochromatic in the range of $2 \theta$ from $10^{\circ}$ to $80^{\circ}$ was used to analyze the tested sample where $2 \theta$ is the angle between the beam and detector.

The tested sample phases were determined by matching the experimental pattern with the standard complied by the Joint Committee on Powder Diffraction Standards (JCPDS).

Figure 3 showed the XRD patterns for two tested samples of the adsorbent materials (clay 1 and clay 2), where they treated for 2 hours which, illustrated that the dominant materials of the first tested sample (clay 1) are Kaolinite $\left(\mathrm{Al}_{2} \mathrm{Si}_{2} \mathrm{O}_{5}(\mathrm{OH})_{4}\right)$, Montmorillonite $\left(\mathrm{NaMgAlSiO}_{2}(\mathrm{OH}) \mathrm{H}_{2} \mathrm{O}\right)$ and Quartz $\left(\mathrm{SiO}_{2}\right)$. It is the sample used in the experimental work. On the other hand, the second tested sample's dominant materials (clay 2) were Kaolinite, Quartz, and Pyrite $\left(\mathrm{FeS}_{2}\right)$.

\section{Scanning Electron Microscope (SEM)}

The shape and size of the tested sample compounds (clay 1) were determined using a scanning electron microscope (SEM). The SEM was utilized to create an image by scanning the surface with a focused electron beam. This beam electron interacts with the tested sample and developing several signals, which were used to give information about the surface topography, morphology, and composition. The SEM instrument is JSM-6390 with an accelerating voltage of $20 \mathrm{kV}$.

Different areas with different magnifications were considered to show the tested sample's important structure (clay 1). SEM with different magnification was done on a dried soil sample to specify the morphological features, as shown in Figure 4.

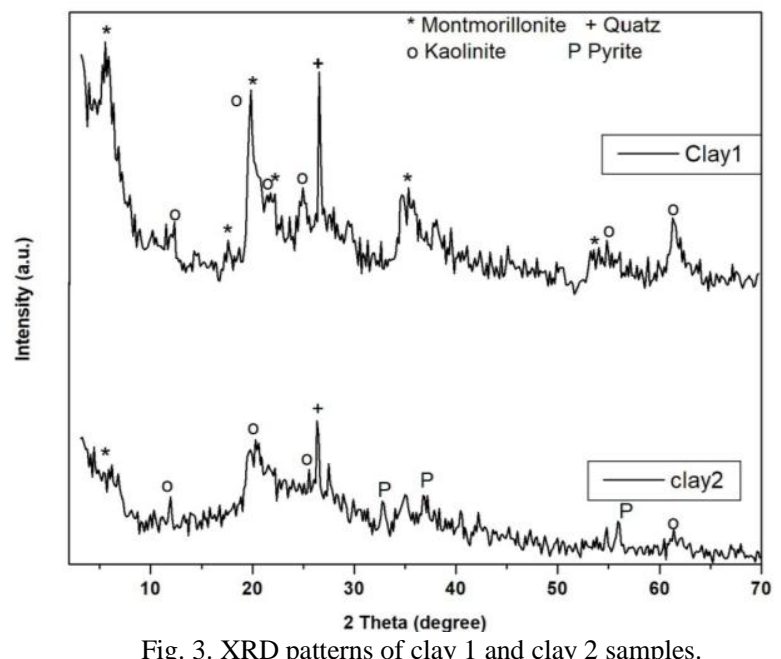

$X$-ray fluorescence $(X R F)$

The tested sample's chemical properties for clay 2 were determined with X-ray fluorescence (XRF) using a wavelength dispersed X-ray fluorescence spectrophotometer that identifies the elemental composition of the materials. This technique is based on measuring the fluorescent X-ray emitted from the tested sample when it is excited by the primary X-ray source. ARLTM QUANT'X EDXRF (Energy Dispersive Xray fluorescence) was used to provide major, minor, and trace element quantification across the sample. Each compound and element was identified by the mass percent concentration $(\mathrm{m} / \mathrm{m} \%)$, which indicates the mass of the component or solute divided by the compound's mass or solute.

\section{RESULTS AND DISCUSSION}

Figures 4A, B, C, and D for soil sample (clay 1) illustrated that there is no specified formation (irregular shape) of the particles of the tested sample using SEM. Figures 4A, B, C, and $\mathrm{D}$ were obtained for the soil sample at different reduction factors, ranging from $1 \square \mathrm{m}$ to $50 \square \mathrm{m}$. Moreover, great spaces were observed between the sample granules, referring to filling these spaces with other materials like the polluted particle.

Study the adsorption behavior of $\mathrm{Fe}$ in aqueous solution through natural peat soil is mainly based on the chemical analyses of the peat soil and Fe aqueous solution samples. The experiments were repeated several times, and average results were obtained for the effect of the experiment variables to ensure the quality of the data.

The chemical compositions of the sample used as adsorbent material using XRF analysis are presented in Table I. The results of this analysis indicated that the tested sample adsorbed the Fe minerals in the solution significantly where the soil adsorbs the Fe pollutant; therefore, the mass percent of $\mathrm{Fe}$ in the soil is $54.22 \%$ of the total mass of the soil sample. It 
enhanced its use in reducing the transfer of pollutants from oxidation ponds to groundwater when lining the bottom of ponds with this peat soil material. Moreover, the results showed that the tested sample tends to absorb the $\mathrm{Fe}$ compound from the solution where the Fe's mass percent in the sample was found as 54.22 .

Complete chemical analyses of samples were carried out in the National Research Center laboratory to clarify the effectiveness of adsorbent material onto $\mathrm{Fe}$.

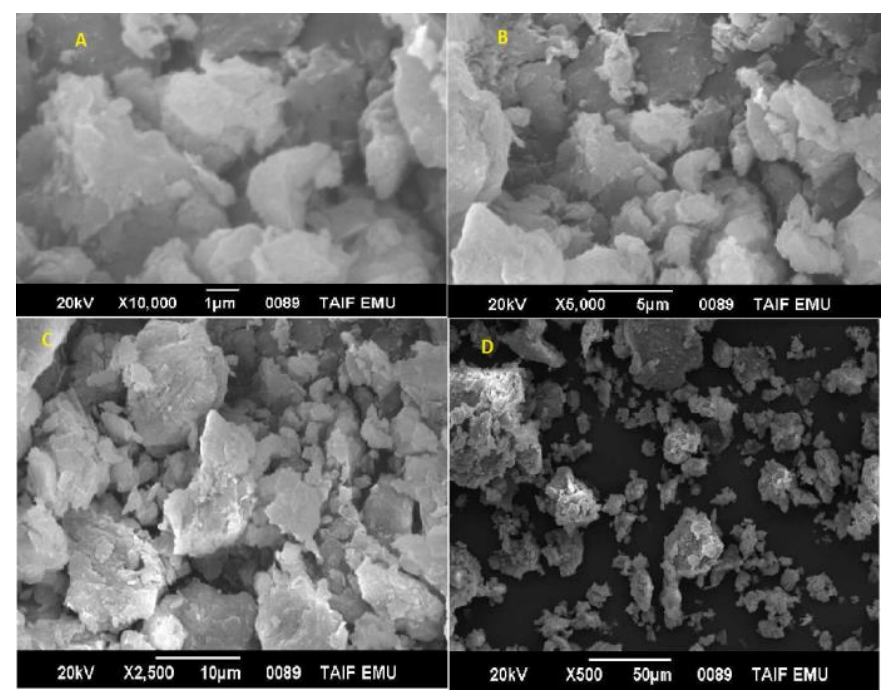

Fig. 4. Scanning electron microscope (SEM) of dry natural peat soil (A), (B), (C), (D).

TABLE I

The Mass Percent Of EACh Compound And Elements In The Tested SoIl (Clay 2) SAMPLE USING XRF ANALYSIS

\begin{tabular}{|c|c|c|c|}
\hline Compound & $\begin{array}{c}\text { Mass percent } \\
\text { concentration } \\
(\mathbf{m} / \mathbf{m} \%) \\
\end{array}$ & Element & $\begin{array}{c}\text { Mass percent } \\
\text { concentration } \\
(\mathbf{m} / \mathbf{m} \%)\end{array}$ \\
\hline $\mathrm{Fe}_{2} \mathrm{O}_{3}$ & 77.53 & $\mathrm{Fe}$ (Iron) & 54.22 \\
\hline $\mathrm{SiO}_{2}$ & 5.77 & Si (Silicon) & 2.7 \\
\hline $\mathrm{CaO}$ & 5.39 & $\mathrm{Ca}$ (calcium) & 3.85 \\
\hline $\mathrm{TiO}_{2}$ & 4.87 & Ti (Titanium) & 2.92 \\
\hline $\mathrm{K}_{2} \mathrm{O}$ & 2.08 & $\mathrm{~K}$ (Potassium) & 1.72 \\
\hline $\mathrm{SO}_{3}$ & 1.28 & $\begin{array}{c}\text { Sx } \\
\text { (Unknown) }\end{array}$ & 0.511 \\
\hline $\mathrm{Al}_{2} \mathrm{O}_{3}$ & 0.824 & $\begin{array}{c}\mathrm{Al} \\
\text { (Aluminum) }\end{array}$ & 0.436 \\
\hline $\mathrm{ZrO}_{2}$ & 0.777 & $\begin{array}{c}\mathrm{Zr} \\
\text { (Zirconium) }\end{array}$ & 0.575 \\
\hline $\mathrm{SrO}$ & 0.35 & Sr (Strontium) & 0.296 \\
\hline $\mathrm{ZnO}$ & 0.214 & Zn (Zinc) & 0.172 \\
\hline $\mathrm{MnO}$ & 0.174 & $\begin{array}{c}\text { Mn } \\
\text { (manganese) }\end{array}$ & 0.134 \\
\hline $\mathrm{NiO}$ & 0.173 & $\mathrm{Ni}$ (Nickel) & 0.136 \\
\hline $\mathrm{CuO}$ & 0.167 & $\mathrm{Cu}$ (Copper) & 0.134 \\
\hline $\mathrm{Cr}_{2} \mathrm{O}_{3}$ & 0.099 & $\begin{array}{c}\mathrm{Cr} \\
\text { (Chromium) }\end{array}$ & 0.068 \\
\hline $\mathrm{Y}_{2} \mathrm{O}_{3}$ & 0.089 & $\mathrm{Y}($ Yttrium $)$ & 0.07 \\
\hline $\mathrm{Rb}_{2} \mathrm{O}$ & 0.088 & $\begin{array}{c}\mathrm{Rb} \\
\text { (Rubidium) }\end{array}$ & 0.08 \\
\hline $\mathrm{Nb}_{2} \mathrm{O}_{5}$ & 0.076 & $\mathrm{Nb}$ (Niobium) & 0.0535 \\
\hline $\mathrm{Ga}_{2} \mathrm{O}_{3}$ & 0.0672 & Ga (Gallium) & 0.0426 \\
\hline
\end{tabular}

TABLE II

PhySiCAL, MAJOR ElEMENTS, AND MinOR ElEMENTS For ANALYZED WATER SAMPLES (RETENTION TIME IS 5HR)

\begin{tabular}{|c|c|c|c|}
\hline Element & unit & $\begin{array}{c}\begin{array}{c}\text { Before } \\
\text { experiment }\end{array} \\
\end{array}$ & $\begin{array}{c}\text { After } \\
\text { experiment }\end{array}$ \\
\hline $\mathrm{pH}$ & ---- & 7.81 & 7.35 \\
\hline $\begin{array}{l}\text { Electrical conductivity } \\
\text { (EC) }\end{array}$ & $\mathrm{ds} / \mathrm{m}^{-1}$ & 3.950 & 0.095 \\
\hline $\begin{array}{c}\text { Total dissolved solids } \\
\text { (TDS) }\end{array}$ & $\mathrm{mg} / \mathrm{L}$ & 2528 & 61 \\
\hline Total alkalinity & $\mathrm{mg} / \mathrm{L}$ & 117 & 52 \\
\hline Nitrite (NO ) & $\mathrm{mg} / \mathrm{L}$ & $<0.2$ & $<0.2$ \\
\hline Nitrate (NO ) & $\mathrm{mg} / \mathrm{L}$ & 0.41 & $<0.2$ \\
\hline Phosphate (PO ) & $\mathrm{mg} / \mathrm{L}$ & 5.28 & $<0.2$ \\
\hline Sulfate (SO ) & $\mathrm{mg} / \mathrm{L}$ & 960.38 & 2.007 \\
\hline Sodium $(\mathrm{Na})$ & $\mathrm{mg} / \mathrm{L}$ & 575 & 17 \\
\hline Chloride $(\mathrm{Cl})$ & $\mathrm{mg} / \mathrm{L}$ & 835.3 & 0.073 \\
\hline Carbonate $\left(\mathrm{CO}_{3}\right)$ & $\mathrm{mg} / \mathrm{L}$ & 0 & 0 \\
\hline
\end{tabular}

Based on the contents of minor ions and acceptable pollutant levels, it is clear from Table II that: The ions' concentration of nitrate and phosphate were decreased from $0.41(\mathrm{mg} / \mathrm{L})$ before experiment to $<0.2(\mathrm{mg} / \mathrm{L})$ after experiment for nitrate and from $5.28(\mathrm{mg} / \mathrm{L})$ before experiment to $<0.2(\mathrm{mg} / \mathrm{L})$ after experiment for phosphate. All the results were expressed in milligrams per liter $(\mathrm{mg} / \mathrm{L})$. Also, it is seen from Table II that the sodium $(\mathrm{Na})$, chloride $(\mathrm{Cl})$, and bicarbonate $\left(\mathrm{HCO}_{3}\right)$ concentrations $(\mathrm{mg} / \mathrm{L})$ decrease after the experiment. Therefore, the peat soil adsorbs incredible amounts of these substances from an aqueous solution.

Based on Table III results, Aluminum ion concentration in the analyzed water samples decreased from $0.18(\mathrm{mg} / \mathrm{L})$ before the experiment to $0.040(\mathrm{mg} / \mathrm{L})$ after the experiment. Barium ion concentration in the analyzed water samples decreased from $0.032(\mathrm{mg} / \mathrm{L})$ before the experiment to 0.011 $(\mathrm{mg} / \mathrm{L})$ after the experiment. Chromium ion concentration in the analyzed water samples decreased from $0.003(\mathrm{mg} / \mathrm{L})$ before experiment to $0.002(\mathrm{mg} / \mathrm{L})$ after experiment. Cobalt ion concentration in the analyzed water samples decreased from $0.034(\mathrm{mg} / \mathrm{L})$ before the experiment to $0.014(\mathrm{mg} / \mathrm{L})$ after the experiment. Copper ion concentration in the analyzed water samples decreased from $0.019(\mathrm{mg} / \mathrm{L})$ before the experiment to $0.018(\mathrm{mg} / \mathrm{L})$ after the experiment. Iron ion concentration in the analyzed water samples decreased from $33.31(\mathrm{mg} / \mathrm{L})$ before the experiment to $22.04(\mathrm{mg} / \mathrm{L})$ after the experiment. Manganese ion concentration in the analyzed water samples decreased from $1.42(\mathrm{mg} / \mathrm{L})$ before the experiment to $0.038(\mathrm{mg} / \mathrm{L})$ after the experiment. Nickel ion concentration in the analyzed water samples decreased from $0.029(\mathrm{mg} / \mathrm{L})$ before the experiment to $0.026(\mathrm{mg} / \mathrm{L})$ after the experiment, and Zinc ion concentration in the analyzed water samples decreased from $0.022(\mathrm{mg} / \mathrm{L})$ before the experiment to $0.013(\mathrm{mg} / \mathrm{L})$ after the experiment. It is clear that the concentration of most heavy metals' elements was decreased after the experiment by passing the polluted water in a column contains the used material due to the effectiveness of peat soil adsorbent. It is observed that iron and all minor and trace elements were influenced and removed from the aqueous solution.

From Table IV, Aluminum ion concentration in the analyzed soil samples increased from $28712(\mathrm{mg} / \mathrm{L})$ before the 
experiment to $36990(\mathrm{mg} / \mathrm{L})$ after the experiment. Barium ion concentration in the analyzed soil samples increased from $185.5(\mathrm{mg} / \mathrm{L})$ before the experiment to $299 \mathrm{mg} / \mathrm{L}$ after the experiment. Chromium ion concentration in the analyzed soil samples increased from $36.8(\mathrm{mg} / \mathrm{L})$ before the experiment to $87(\mathrm{mg} / \mathrm{L})$ after the experiment. Cobalt ion concentration in the analyzed soil samples increased from $12(\mathrm{mg} / \mathrm{L})$ before the experiment to $42(\mathrm{mg} / \mathrm{L})$ after the experiment. Copper ion concentration in the analyzed soil samples increased from $106.4(\mathrm{mg} / \mathrm{L})$ before the experiment to $464(\mathrm{mg} / \mathrm{L})$ after the experiment. Iron ion concentration in the analyzed soil samples increased from $19480(\mathrm{mg} / \mathrm{L})$ before the experiment to $63360(\mathrm{mg} / \mathrm{L})$ after the experiment. Lead ion concentration in the analyzed soil samples increased from $7.2(\mathrm{mg} / \mathrm{L})$ before the experiment to $113(\mathrm{mg} / \mathrm{L})$ after the experiment. Manganese ion concentration in the analyzed soil samples increased from $336(\mathrm{mg} / \mathrm{L})$ before the experiment to $1060(\mathrm{mg} / \mathrm{L})$ after the experiment. Nickel ion concentration in the analyzed soil samples increased from $43.6(\mathrm{mg} / \mathrm{L})$ before the experiment to $107(\mathrm{mg} / \mathrm{L})$ after the experiment, and Zinc ion concentration in the analyzed soil samples increased from $93.2(\mathrm{mg} / \mathrm{L})$ before the experiment to $283(\mathrm{mg} / \mathrm{L})$ after the experiment.

\section{EFFect Of Some Parameters On The Removal EFFICIENCY (\%) AND ADSORPTION CAPACITY}

Several experimental works were carried out to investigate the performance of some parameters such as the contact time, the $\mathrm{Fe}$ initial concentration, and adsorbent dose on the $\mathrm{Fe}$ removal (\%) and adsorption capacity.

In Figure 5, the relation between the $\mathrm{Fe}$ residual concentration $(\mathrm{mg} / \mathrm{L})$ and the contact time (hr.) with different Fe initial concentrations $(\mathrm{mg} / \mathrm{L})$ was investigated. The results showed that an increase in the contact time resulted in a decrease in the $\mathrm{Fe}$ residual concentration at the same $\mathrm{Fe}$ initial concentration. For example, at the same $\mathrm{Fe}$ initial concentration of $100(\mathrm{mg} / \mathrm{L})$, when the contact time was 5 (hrs.), the $\mathrm{Fe}$ residual concentration was $51(\mathrm{mg} / \mathrm{L})$ and decreased to $40(\mathrm{mg} / \mathrm{L})$ when the contact time increased to 20 (hrs.) since the adsorbent material can continuously absorb the Fe from the aqueous solution with increasing the contact time. On the other hand, when the Fe initial concentration increased, the Fe residual concentration increased simultaneously.

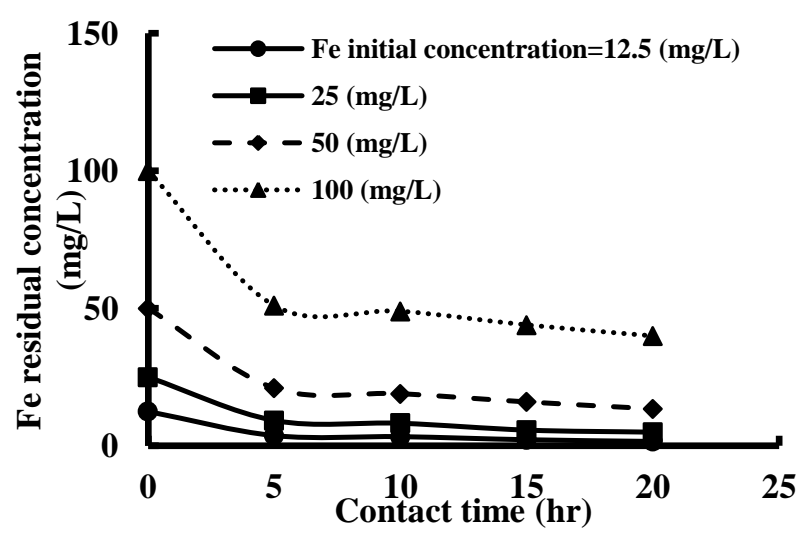

Fig. 5. Variation of the Fe residual concentration (mg/with the contact time at different $\mathrm{Fe}$ initial concentrations (adsorbent dose $175(\mathrm{~g})$, temperature $25^{\circ} \mathrm{C}$, $\mathrm{pH}=7.4$ ).
TABLE III

TRACE ELEMENT Of THE ANALyZED WATER SAMPLES (RETENTION TIME IS 5HR)

\begin{tabular}{c||c||c||c} 
Element & unit & $\begin{array}{c}\text { Concentration } \\
\text { before } \\
\text { experiment }\end{array}$ & $\begin{array}{c}\text { Concentration } \\
\text { after experiment }\end{array}$ \\
\hline Aluminum $(\mathrm{Al})$ & $\mathrm{mg} / \mathrm{L}$ & 0.181 & 0.040 \\
\hline Antimony $(\mathrm{Sb})$ & $\mathrm{mg} / \mathrm{L}$ & $<0.009$ & $<0.009$ \\
\hline Arsenic $(\mathrm{As})$ & $\mathrm{mg} / \mathrm{L}$ & $<0.006$ & $<0.006$ \\
\hline Barium $(\mathrm{Ba})$ & $\mathrm{mg} / \mathrm{L}$ & 0.032 & 0.011 \\
\hline Cadmium $(\mathrm{Cd})$ & $\mathrm{mg} / \mathrm{L}$ & $<0.002$ & $<0.002$ \\
\hline Chromium $(\mathrm{Cr})$ & $\mathrm{mg} / \mathrm{L}$ & 0.003 & 0.002 \\
\hline Cobalt $(\mathrm{Co})$ & $\mathrm{mg} / \mathrm{L}$ & 0.034 & 0.014 \\
\hline Copper $(\mathrm{Cu})$ & $\mathrm{mg} / \mathrm{L}$ & 0.018 & 0.019 \\
\hline Iron $(\mathrm{Fe})$ & $\mathrm{mg} / \mathrm{L}$ & 33.31 & 22.04 \\
\hline Lead $(\mathrm{Pb})$ & $\mathrm{mg} / \mathrm{L}$ & $<0.007$ & $<0.007$ \\
\hline Manganese $\mathrm{Mn}$ & $\mathrm{mg} / \mathrm{L}$ & 1.416 & 0.038 \\
\hline Nickel $(\mathrm{Ni})$ & $\mathrm{mg} / \mathrm{L}$ & 0.029 & 0.026 \\
\hline Selenium $(\mathrm{Se})$ & $\mathrm{mg} / \mathrm{L}$ & $<0.007$ & $<0.007$ \\
\hline Tin $(\mathrm{Sn})$ & $\mathrm{mg} / \mathrm{L}$ & $<0.006$ & $<0.006$ \\
\hline Vanadium $(\mathrm{V})$ & $\mathrm{mg} / \mathrm{L}$ & $<0.001$ & $<0.001$ \\
\hline Zinc $(\mathrm{Zn})$ & $\mathrm{mg} / \mathrm{L}$ & 0.022 & 0.013
\end{tabular}

TABLE IV

TRACE ELEMENTS OF THE ANALYZED PEAT SOIL SAMPLES (RETENTION TIME IS 5HR)

\begin{tabular}{c||c||c||c||c}
\multicolumn{1}{c||}{ Element } & unit & $\begin{array}{c}\text { Concentration } \\
\text { before } \\
\text { experiment }\end{array}$ & \multicolumn{2}{c}{$\begin{array}{c}\text { Concentration after } \\
\text { experiment }\end{array}$} \\
\cline { 2 - 3 } Aluminum $(\mathrm{Al})$ & $\mathrm{mg} / \mathrm{L}$ & 28712 & 29550 & 36990 \\
\hline Antimony $(\mathrm{Sb})$ & $\mathrm{mg} / \mathrm{L}$ & $\mathrm{DL}$ & $<0.009$ & $<0.009$ \\
\hline Arsenic $(\mathrm{As})$ & $\mathrm{mg} / \mathrm{L}$ & $\mathrm{DL}$ & $<0.006$ & $<0.006$ \\
\hline Barium $(\mathrm{Ba})$ & $\mathrm{mg} / \mathrm{L}$ & 185.2 & 197 & 299 \\
\hline Cadmium $(\mathrm{Cd})$ & $\mathrm{mg} / \mathrm{L}$ & $\mathrm{DL}$ & $<0.002$ & $<0.002$ \\
\hline Chromium $(\mathrm{Cr})$ & $\mathrm{mg} / \mathrm{L}$ & 36.8 & 77 & 87 \\
\hline Cobalt $(\mathrm{Co})$ & $\mathrm{mg} / \mathrm{L}$ & 12 & 39 & 42 \\
\hline Copper $(\mathrm{Cu})$ & $\mathrm{mg} / \mathrm{L}$ & 106.4 & 261 & 464 \\
\hline Iron $(\mathrm{Fe})$ & $\mathrm{mg} / \mathrm{L}$ & 19480 & 52260 & 63360 \\
\hline Lead $(\mathrm{Pb})$ & $\mathrm{mg} / \mathrm{L}$ & 7.2 & 87 & 113 \\
\hline Manganese & $\mathrm{mg} / \mathrm{L}$ & 336 & 952 & 1060 \\
\hline (Mn) & $\mathrm{mg} / \mathrm{L}$ & 43.6 & 98 & 107 \\
\hline Nickel $(\mathrm{Ni})$ & $\mathrm{mg})$ & $\mathrm{DL}$ & $<0.007$ & $<0.007$ \\
\hline Selenium $(\mathrm{Se})$ & $\mathrm{mg} / \mathrm{L}$ & $\mathrm{DL}$ & $<0.006$ & $<0.006$ \\
\hline Tin $(\mathrm{Sn})$ & $\mathrm{mg} / \mathrm{L}$ & 138.4 & 123 & 125 \\
\hline Vanadium $(\mathrm{V})$ & $\mathrm{mg} / \mathrm{L}$ & 93.2 & 240 & 283
\end{tabular}

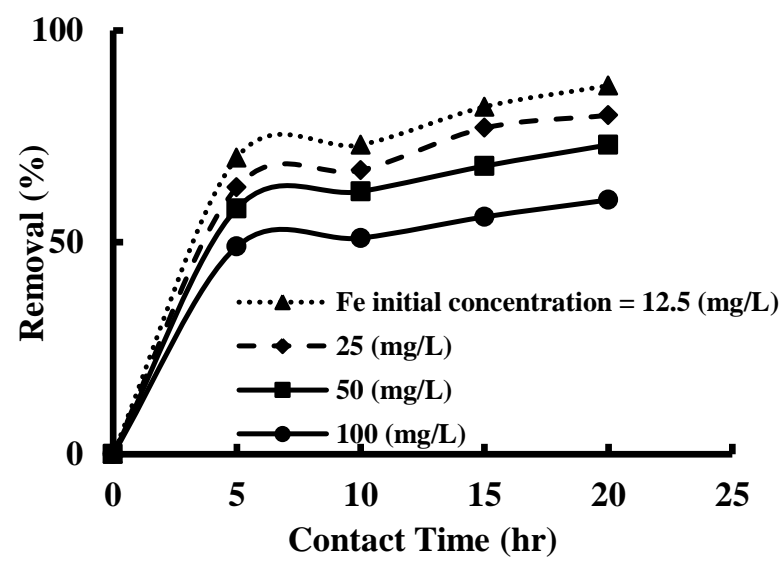

Fig. 6. Variation of the removal (\%) with contact time (hr.) at different $\mathrm{Fe}$ initial concentrations (adsorbent dose $175(\mathrm{~g})$, temperature $25^{\circ} \mathrm{C}$, $\mathrm{pH}=7.4$ ). 
The removal $(\%)$ can be computed as the difference between the $\mathrm{Fe}$ initial concentration and the $\mathrm{Fe}$ residual concentration at the specified time divided by the $\mathrm{Fe}$ initial concentration as follows,

$$
\text { Removal (\%) }=\frac{\mathrm{C}_{0}-\mathrm{C}_{\mathrm{t}}}{\mathrm{C}_{0}} * 100
$$

where $\mathrm{C}_{0}$ is the $\mathrm{Fe}$ initial concentration $(\mathrm{mg} / \mathrm{L})$, and $\mathrm{C}_{\mathrm{t}}$ is the Fe residual concentration $(\mathrm{mg} / \mathrm{L})$ at the specified time.

Figure 6 illustrated the relationship between the removal (\%) and contact time at different Fe initial concentrations using Equation (1). The removal efficiency was investigated at various Fe initial concentrations from 12.5 to 100 (mg/L), adsorbent dose $175(\mathrm{~g}), \mathrm{pH}$ value 7.4 , and a temperature of $25\left({ }^{\circ} \mathrm{C}\right)$. The effects of both $\mathrm{C}_{0}$ and solution/adsorbent contact time $\mathrm{C}_{\mathrm{t}}$ on the removal efficiency were showed. The removal efficiency is directly proportional to contact time at the same $\mathrm{Fe}$ initial concentration. An increase in the contact time increased the removal (\%) at the same $\mathrm{Fe}$ initial concentration, for example, at the same $\mathrm{Fe}$ initial concentration $12.5(\mathrm{mg} / \mathrm{L})$, when the contact time was $5(\mathrm{hr})$, the removal (\%) was $70(\%)$. This value was $87(\%)$ at $20(\mathrm{hr})$. The maximum removal (\%) was $87(\%)$, at a high contact time of $20(\mathrm{hr})$ and low Fe initial concentration of $12.5(\mathrm{mg} / \mathrm{L})$.

Figure 7 illustrated that an increase in the $\mathrm{Fe}$ initial concentration led to a reduction in the removal (\%) at the same contact time since the term of the Fe initial concentration was in the denominator of Equation (1). The removal efficiency is computed based on Equation (1), where the $C_{t}$ is the Fe's concentration in the solutions at a specified time t. If the contact time is increased, the removal efficiency \% is also increased, reaching $87 \%$ when the contact time $20 \mathrm{hrs}$. At $12.5 \mathrm{mg} / \mathrm{L}$ of $\mathrm{Fe}$ and this is obvious in Fig. 7. For another example, for 5 (hr) contact time, when the $\mathrm{Fe}$ initial concentration was $12.5(\mathrm{mg} / \mathrm{L})$, the removal (\%) was $70(\%)$ and decreased to $49(\%)$ at $100(\mathrm{mg} / \mathrm{L})$.

Figure 8 explained the effect of the adsorbent thickness variation on the removal $(\%)$ at different contact times and constant Fe initial concentration $12.5(\mathrm{mg} / \mathrm{L})$. It is shown from Figure 4 that an increase in the adsorbent thickness in aqueous solution resulted in a rise in the removal (\%) at the same contact time and Fe initial concentration $12.5(\mathrm{mg} / \mathrm{L})$ which, mean that removal efficiency is directly proportional to adsorbent thickness at the same contact time. When no soil in an aqueous solution, there is NO removal of Fe from the aqueous solution, and when the adsorbent thickness was 1 $(\mathrm{cm})$, the removal $(\%)$ was $42(\%)$ at $5(\mathrm{hr})$ contact time. The removal (\%) increased to $70(\%)$ when the adsorbent thickness became $4(\mathrm{~cm})$. An increase in the contact time indicated an increase in the removal (\%) when the adsorbent thickness was constant. The maximum removal (\%) was $90 \%$ occurred at high adsorbent dose $210(\mathrm{~g})$, high adsorbent thickness $5(\mathrm{~cm})$, and high contact time 20 (hr).

Figure 9 explained the effect of the adsorbent weight $(\mathrm{g})$ on the removal (\%) at different contact times and constant $\mathrm{Fe}$ initial concentration $12.5(\mathrm{mg} / \mathrm{L}), \mathrm{pH}$ value of 7.4 , and a temperature of $25\left({ }^{\circ} \mathrm{C}\right)$. The adsorbent weight was increased from 50 to $210(\mathrm{~g})$. Its effect is the same as the adsorbent thickness. An increase in the adsorbent thickness led to a rise in the adsorbent weight. It indicates that as the adsorbent weight increases, Fe's available adsorption sites increase, helping to achieve higher removal efficiency.

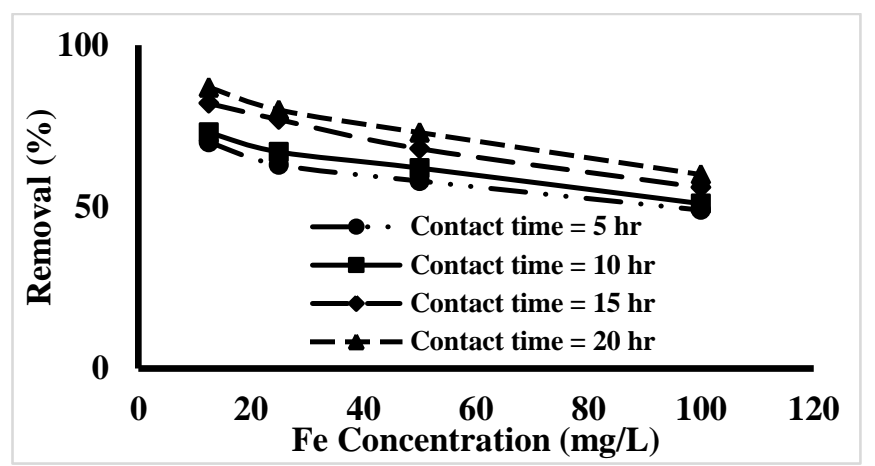

Figure 7. Variation of the removal (\%) with the Fe initial concentration $(\mathrm{mg} / \mathrm{L})$ at different contact time (adsorbent dose $175(\mathrm{~g})$, temperature $25 \mathrm{oC}$, $\mathrm{pH}=7.4)$.

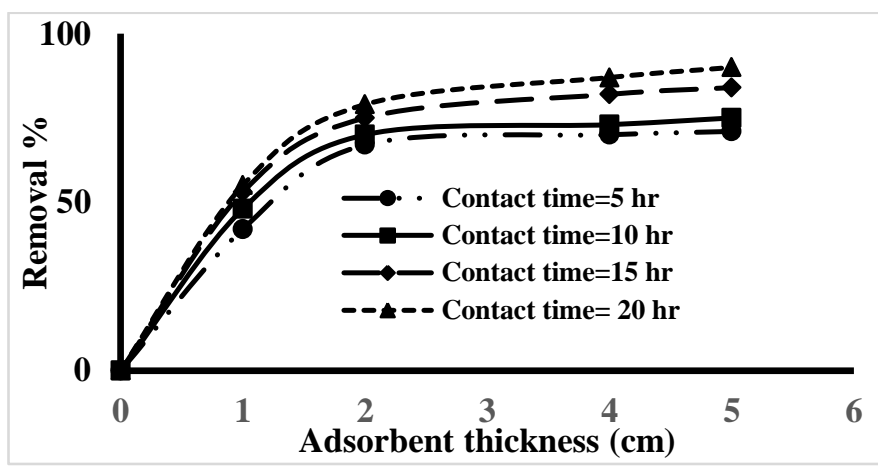

Fig. 8. Variation of the removal $(\%)$ with the adsorbent thickness $(\mathrm{cm})$ at different contact times ( $\mathrm{Fe}$ initial concentration $12.5 \mathrm{mg} / \mathrm{L}$, temperature $25^{\circ} \mathrm{C}$, $\mathrm{pH}=7.4)$.

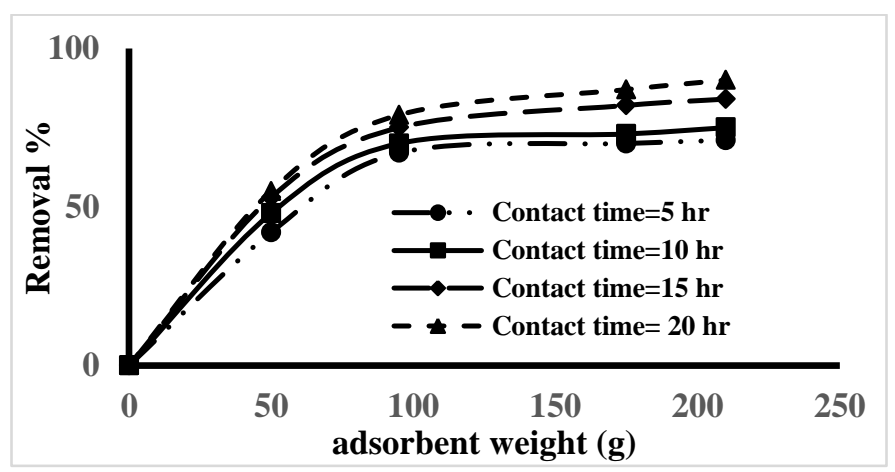

Fig. 9. Variation of the removal (\%) with the adsorbent weight (g) at different contact time ( $\mathrm{Fe}$ initial concentration $12.5(\mathrm{mg} / \mathrm{L})$, temperature $25 \mathrm{oC}, \mathrm{pH} 7.4)$.

The adsorbent weight $(\mathrm{g})$ effect on the adsorption capacity $(\mathrm{mg} / \mathrm{g})$ was discussed. The adsorption capacity (A) in $(\mathrm{mg} / \mathrm{g})$ can be determined as

$$
\mathrm{A}=\frac{\mathrm{C}_{0}-\mathrm{C}_{\mathrm{t}}}{\mathrm{m}} \mathrm{V} \quad(\mathrm{mg} / \mathrm{g})
$$

where $\mathrm{C}_{0}$ is the $\mathrm{Fe}$ initial concentration $(\mathrm{mg} / \mathrm{L}), \mathrm{C}_{\mathrm{t}}$ is the $\mathrm{Fe}$ residual concentration in aqueous solution $(\mathrm{mg} / \mathrm{L}), \mathrm{m}$ is the adsorbent mass $(\mathrm{g})$, and $\mathrm{V}$ is the solution volume $(\mathrm{L})$.

Figure 10 showed the influence of adsorbent weight on the adsorption capacity of the peat soil. The experiment was 
conducted using the same Fe initial concentration 12.5 (mg/L).

In the above question, the initial concentration $\mathrm{C}_{0}$ as 12.5 $\mathrm{mg} / \mathrm{L}$ and final concentration $\left(\mathrm{C}_{\mathrm{t}}\right)$ as $7.5 \mathrm{mg} / \mathrm{L}$ of $\mathrm{Fe}$ at a contact time of $5 \mathrm{hr}$ is presented as an example. The volume is $1000 \mathrm{ml}$, and the amount of adsorbent used (peat soil) is 50 gm.

Now we use the formula to compute A

$\mathrm{A}=[(12.5-7.5) \mathrm{mg} / \mathrm{L} * 1 \mathrm{~L}] / 50 \mathrm{gm}$ or $\mathrm{A}=[5 \mathrm{mg} / 50 \mathrm{gm}]$ or $\mathrm{A}=0.1 \mathrm{mg} / \mathrm{gm}$. Thus $0.1 \mathrm{mg}$ of $\mathrm{Fe}$ ions are adsorbed by 1 gm of peat soil. The A value you have got for the contact time of $5 \mathrm{hr}$.

It was found that the adsorption capacity decreased from 0.1 to $0.04(\mathrm{mg} / \mathrm{g})$ with an adsorbent weight increased from 50 to 210 (g). As in Equation (2), the adsorption capacity depends on the mass of the adsorbent, the solution volume, and the Fe's initial concentration. The adsorption capacity was computed when the Fe's initial concentration was $12.5 \mathrm{mg} / \mathrm{L}$, and the solution volume is considered $1 \mathrm{~L}$. Therefore, the adsorption capacity is low, and when the initial concentration of $\mathrm{Fe}$ is increased, then the adsorption capacity will also be increased. It concludes that the percentage adsorbent area that adsorbs the polluted metals and occupied by adsorption ions reduced.

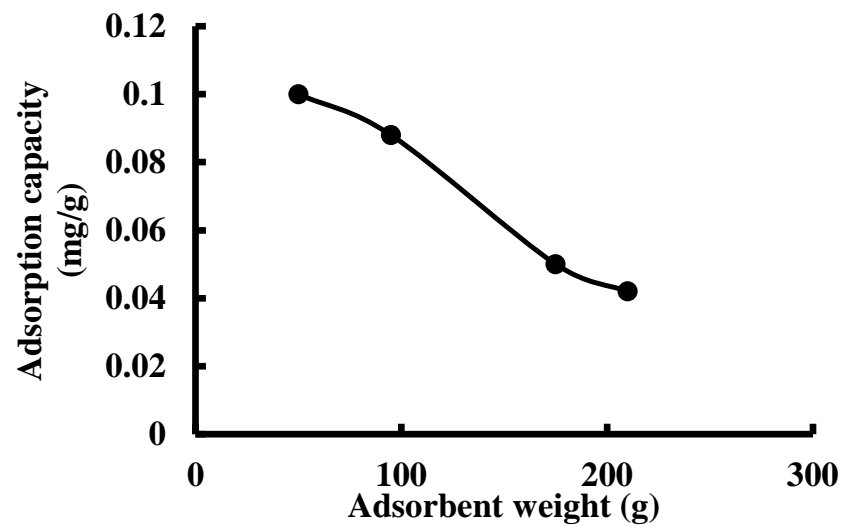

Fig. 10. Variation of the adsorption capacity $(\mathrm{mg} / \mathrm{g})$ with the adsorbent weight (g) $\left(\mathrm{Fe}\right.$ initial concentration $12.5 \mathrm{mg} / \mathrm{L}$, temperature $\left.25^{\circ} \mathrm{C}, \mathrm{pH} 7.4\right)$

\section{CONCLUSION AND RECOMMENDATION}

Laboratory experiments confirmed that the organic soil layer extending down most of Egypt's delta lands acts as an adsorption medium, especially to remove the iron element from the groundwater.

Under normal conditions and without any activation, the organic layer acts as a slow adsorbent, and the adsorption capacity reaches up to $0.1 \mathrm{mg} F$ for $50 \mathrm{mg}$ from the adsorbent.

From the experimental results presented in this study, the efficacy of natural peat soil to adsorb the heavy metals from water has been ascertained widely concerning different parameters such as the material thickness, contact time, initial concentration of the heavy metals, and the adsorbent dose. Furthermore, this natural peat soil can cover the bottom surface of the oxidation ponds, streams, and canals to avoid contaminating the groundwater.

\section{REFERENCES}

[1] F. Fu, and Q. Wang, "Removal of heavy metal ions from wastewaters, A review," Journal of Environmental Management 92, (3), pp. 407-418, 2011

[2] M. W. Wan, C. C. Wang, and C. M. Shen, "The Adsorption study of copper removal by chitosan-coated sludge derived from water treatment plant" International journal of environmental science and development, vol. 4, No. 5, pp. 545-551, Oct. 2013.

[3] C. T. Onwordi, C. C. Uche, A. E. Ameh and L. F. Petrik, "Comparative study of the adsorption capacity of lead (II) ions onto bean husk and fish scale from aqueous solution", Journal of water reuse and desalination, 9 (3): pp. 249-262, Sep. 2019.

[4] P. Chintalapudi, P. Pujari, G. Khadse, R. Sanam, P. Labhasetwar, "Groundwater quality assessment in emerging industrial cluster of alluvial aquifers near Jaipur, India", Environ Earth Sci, 76, 8, pp. 1-14, Jan. 2017.

[5] I. Yolcuba, O. Z. Guündüz and F. Sönmez, "Assessment of impact of environmental pollution on groundwater and surface water qualities in a heavily industrialized district of Kocaeli, Dilovas, Turkey", Environ Earth Sci, 75, 170, pp. 1-23, Jan. 2016.

[6] J. Wu, and Z. Sun, "Evaluation of shallow groundwater contamination and associated human health risk in an alluvial plain impacted by agricultural and industrial activities, Mid-west China", Expo Health, 8, pp. 311-329, Jan. 2016.

[7] O. Ali, T. Abdel-Fattah, and H. E. Elsayed, "Copper cation removal in electro kinetic cell containing zeolite", Journal of hazardous materials, vol. 185, pp. 1550-1557, 2011.

[8] H. Gogoi, T. Leiviskä, E. Heiderscheidt, H. Postila, J. Tanskanen, "The effectiveness of metal and metalloid sorption from mining influenced waters by natural and modified peat", mine water and the Environment, 37, pp.734-743, 2018.

[9] A. Menció, J. Mas-Pla, N. Oteroc, O. Regàs, M. Boy-Roura, R. Puig, J. Bach, C. Domènech, M. Zamorano, D. Brusi, A. Folche, "Nitrate pollution of groundwater; all right..., but nothing else?", Science of the total environment, 539, pp. 241-251, 2016

[10] M. H. El Sayed, A. M. El Aassar, M. M. Abo El Fadl, and A. M. Abd El Gawad, "Hydro-geochemistry and pollution problems in 10th of Ramadan city, east El Delta, Egypt", Journal of applied sciences research, 8(4), pp. 1959-1972, 2012.

[11] E. E. Hussein, M. Fouad, M. I. Gad, "Prediction of the pollutants movements from the polluted industrial zone in 10th of Ramadan city to the quaternary aquifer", Applied water science, 9:20, pp. 1-19, 2019

[12] L. M. Plum, L. Rink, and H. Haase, "The Essential toxin: impact of zinc on human health" International Journal of Environmental research and public health, 7, 1342-1365, 2010.

[13] WHO "Guidelines for drinking-water-quality", 4th Edition. World Health Organisation, Geneva, pp. 541, 2011.

[14] L. Canet, M. Ilpide, P. Seta, "Efficient facilitated transport of lead, cadmium, zinc, and silver across a flat-sheet-supported liquid membrane mediated by lasalocid A", Separation Science and Technology, 37(8), pp. 1851-1860, 2002

[15] O. J. Esalah, M. E. Weber, J. H. Vera, "Removal of lead, cadmium and zinc from aqueous solutions by precipitation with sodium di-(n-octyl) phosphate", The Canadian Journal of Chemical Engineering, 78(5), pp. 948-954, 2000.

[16] F. Ciesielczyk, P. Bartczak, K. Wieszczycka, K. Siwinska-Stefanska, M. Nowacka, T. Jesionowski, "Adsorption of Ni (II) from model solutions using co-precipitated inorganic oxides", Adsorption, 19, pp. 423-434, 2013.

[17] D. Kołodynska, M. Kowalczyk, Z. Hubicki, "Evaluation of iron-based hybrid materials for heavy metal ions removal", Journal of Material Science, 49, pp. 2483-2495, 2014.

[18] F. Ouadjenia, R. Marouf, J. Schott, A. Yahiaoui, "Removal of $\mathrm{Cu}(\mathrm{II})$, $\mathrm{Cd}(\mathrm{II})$ and $\mathrm{Cr}(\mathrm{III})$ ions from aqueous solution by dam silt", Arabian Journal of Chemistry, 6, pp. 401-406, 2013.

[19] P. Rudnicki, Z. Hubicki, and D. Kołodynska, "Evaluation of heavy metal ions removal from acidic wastewater streams", Chemical engineering journal, 252, pp. 362-373, 2014.

[20] Ł. Klapiszewski, P. Bartczak, M. Wysokowski, M. Jankowska, K. Kabat, T. Jesionowski, "Silica conjugated with kraft lignin and its use as a novel 'green' sorbent for hazardous metal ions removal", Chemical engineering journal, 260, pp. 684-693, 2015. 
[21] T. N. Abhilash, A. M. Mansoor, "The reuse of water treatment sludge as a coagulant for post-treatment of UASB reactor treating urban wastewater", Journal of Cleaner Production 96, pp. 272-281, 2015.

[22] S. Gabche, J. Mbadcam, D. R. Tchuifon, and N. J. Ndi, "Kinetic and equilibrium studies of the adsorption of the mercury (II) ions from aqueous solution using kaolinite and meta kaolinite clays from southern Cameron", International Journal Research on Chemical Environment 3(2): pp. 1-11, 2013.

[23] M. M. Areco, L. Saleh-Medina, M. A. Trinelli, J. L. Marco-Brown, M. Dos Santos Afonso, "Adsorption of $\mathrm{Cu}(\mathrm{II}), \mathrm{Zn}(\mathrm{II}), \mathrm{Cd}(\mathrm{II})$ and $\mathrm{Pb}$ (II) by dead avena fatuabiomass and the effect of these metals on their growth", Colloids Surface B: Biointerfaces, 110, pp. 305-312, 2013.

[24] S. Shahin, M. Mossad, M. Fouad, "Evaluation of copper removal efficiency using water treatment sludge", Water science and engineering, Volume 12, Issue 1, pp. 37-44, 2018.

[25] J. Nsami, J. Mbadcam, "The adsorption efficiency of chemically prepared activated carbon from cola nut shells by $\mathrm{ZnCl}_{2}$ on methylene blue", Publishing corporation journal of chemistry, ID 469170: 7, 2013.

[26] A. Robalds, "Sorption of thallium (I), copper (II), chromium (III) and phosphate by peat based biosorbents", Ph.D. thesis, University of Latvia, 2016.

[27] P. Bartczak, M. Norman, Ł. Klapiszewski, N. Karwan'ska, M. Kawalec, M. Baczyn'ska, M. Wysokowski, J. Zdarta, F. Ciesielczyk, T. Jesionowski, "Removal of nickel (II) and lead (II) ions from aqueous solution using peat as a low-cost adsorbent: A kinetic and equilibrium study", Arabian journal of chemistry 11, pp. 1209-1222, 2018.

[28] R. A. K. Rao, and M. Kashifuddin, "Adsorption studies of Cd (II) on ball clay: comparison with other natural clays", Arabian Journal of Chemistry, 9 (Suppl. 2), S1233-S1241, 2016.

[29] I. Kara, D. Tunc, F. Sayin, S. T. Akar, "Study on the performance of metakaolin based geopolymer for $\mathrm{Mn}$ (II) and Co(II) removal", Applied clay science, 161, pp.184-193, 2018.

[30] N. M. Malima E. H. Lugwisha, A. S. Mwakaboko, "The efficacy of raw malangali kaolin clay in the adsorptive removal of cadmium and cobalt ions from water", Tanzania Journal of science, 44(2), pp. 64-80, 2018.

[31] A. Bourliva, A. K. Sikalidis, L. Papadopoulou, M. Betsiou, K. Michailidis, C. Sikalidis, and A. Filippidis, "Elimination of $\mathrm{Cu} 2+$ and $\mathrm{Ni} 2+$ ions in aqueous solutions by adsorption onto natural attapulgite and vermiculite", Mineralogical Magazine, 2018.

[32] F. A. Temel, N. G. Turan, O. Ozgonenel, Y. Ardal1, "The use of response surface methodology for modelling of lead (II) removal from industrial waste by pumice and vermiculite", International Journal of global warming, vol. 15, No. 2, pp. 175-189, 2018.

[33] S. Pandey, "A comprehensive review on recent developments in bentonite-based materials used as adsorbents for wastewater treatment", Journal of molecular liquids, Volume 241, pp. 1091-1113, Sep. 2017.

[34] S. F. Lim, A.Y.W. Lee, "Kinetic study on removal of heavy metal ions from aqueous solution by using soil". Environmental Science and Pollution Research,22, 3, pp.163-167, 2015.
[35] G. Vijayakumar, R. Tamilarasan, M. Dharmendirakumar, "Adsorption, kinetic, equilibrium and thermodynamic studies on the removal of basic dye rhodamine-B from aqueous solution by the use of natural adsorbent perlite", Journal of Materials and Environmental Science, 3 (1), pp. 157$170,2011$.

[36] S.,Hajji, and N., Mzoughi, "Kinetic, equilibrium and thermodynamic studies for the removal of lead ions from aqueous solutions by using low cost adsorbents: a comparative study", IOSR Journal of applied chemistry (IOSR-JAC), vol. 11, Issue 7 Ver, I, PP 12-24, July 2018.

[37] K. Omar, P. Palaniandy, "A Preliminary study of heavy metals removal from synthetic rainwater by natural mineral adsorbents", Sci., int.(Lahore),29(2),pp.19-23, 2017.

[38] M. Imamoglu, and T. Oktay, "Removal of copper (II) and lead (II) ions from aqueous solutions by adsorption on activated carbon from a new precursor hazelnut husks", Desalination, 228, pp. 108-113, 2007.

[39] N. Y. Rachel, N. J. Nsami, B. B. Placide, K. Daouda, A. A.Victoire, T. M. Benadette and K. J. Mbadcam, "Adsorption of manganese(II) Ions from aqueous solutions onto granular activated carbon (GAC) and modified activated carbon (MAC)", International journal of innovative science, engineering \& Technology, Vol. 2 Issue 8, pp. 606-614, 2015.

[40] K. T. Osman, "Management of soil problems", springer international publishing AG, chapter 7, page 145, 2018.

[41] I. M. El- Naggar, Sayed A. Ahmed, Nabila Shehata, E. S. Sheneshen, Mahmoud Fathy, Amr Shehata, "A novel approach for the removal of lead (II) ion from wastewater using Kaolinite/Smectite natural composite adsorbent", Applied Water Science 9:7, p. 1-13, 2019.

[42] S. Ahmadi, C. Osagie, S. Rahdar, N. A. Khan, S. Ahmed, H. Hajini, "Efficacy of persulfate- based advanced oxidation process (US/PS/Fe3O4) for ciprofloxacin removal from aqueous solutions", Applied Water Science, 10:187, pp. 1-6, 2020.

\section{Title Arabic:}

$$
\text { سلوك الامتزاز لأيون الحديد من المياه الجوفية عبر تربة الخث الطبيعية }
$$

\section{Arabic Abstract:}

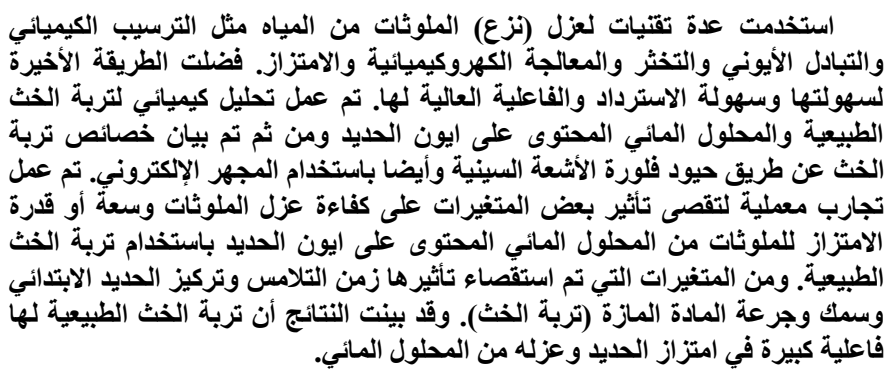

